\title{
From "Walled-Up Wife" to a "Room of One's Own:" Gender and Migration among Macedonians in Germany
}

\author{
Lidija Stojanović \\ Institute of Folklore "Marko Cepenkov," Skopje, Macedonia \\ It is the transfiguring light that \\ distinguishes one experience from \\ another, happening from experience; \\ it is life itself before thought has \\ shaped it. The "feminine" is universal \\ and yet transitory, and it can be \\ expressed only by brittle half- \\ phrases, symbols, poetry. \\ Virginia Woolf
}

\section{Introduction}

When people undertake that enormous and decisive step in their lives that constitutes migration, what happens to the habitus?(1) For Bourdieu, habitus indicates a cultural structure existing in the body and mind of each individual. The individual develops a system of dispositions in response to the objective conditions he/she encounters. This system comprises lasting, acquired schemes of perception, thought and action. Crucially, habitus is not a static or mechanical status quo, but is established through continuous changes causing transformations to the habitus in the course of a lifetime. The habitus is modifying and transformational within the borders of its own structure. In the context of habitus, then, what happens to gender when people move to another country, that is to say, in what manner do they construct or reconstruct traditional gender relations in the process of international migration, and how does gender shape and reshape migration?

The small-scale piece of fieldwork that is discussed below will focus on one aspect of the complex investigation of migration: the relationship between migration, space and gender. It is based on a threemonth period of fieldwork conducted in Hamburg in 2003, in which the method of qualitative narrative interview was employed, one in which the informant is left to interpret his/her own life story with as little interruption and intervention as possible, in order to conceive and analyze the internal rules between experience and narration. It was followed by participant observation in households, families, and religious celebrations in the Macedonian church of St. Georgi Kratovski. Thirtyeight qualitative interviews were recorded,(2) and ten records made of 
participant observation of various events and celebrations, such as religious festivals in church or people's homes, birthday parties, picnics, two concerts in a Musikhochschule and a number of unofficial personal visits. In order to place my data in context and analyze it, I will first consider the nature of Macedonian emigration to Germany. I shall then turn to a discussion of the defining characteristics of my field of research, and consideration of the relationship between migration and gender in the light of Bourdieu's theory of habitus.

The periodization and categorization of Macedonian migration to Germany

My research covers a certain period and specific categories of migrant. The period begins in the late 1960's and goes up to the present day. The first Macedonian migrants in Germany were organized groups of workers who left their homeland (then the SFR of Yugoslavia) following an intergovernmental agreement. Their motives for emigrating may be regarded as traditional: they went abroad to seek employment. The process of emigration is still continuing, though it now affects those who are part of what is often termed the brain-drain. The following list reflects the categories and timescale of Macedonian migration to the German industrial city of Hamburg. It may usefully serve as a matrix for considering the data and for determining inter-gender relations, both as far as the individual and the group, collective habitus is concerned.

- Gastarbeitergruppe (groups of guest workers) who arrived 19691973.

- Nurses, who arrived in Hamburg in 1990 and 1991 (and who were employed at the Universitätsklinikum in Eppendorf).

- Asylum seekers, who came to Germany during the Balkan crisis of 1991-1994

- The highly educated, a category of migrants who comprise the brain-drain, and are characteristic of the decade from 1993-2003. These are graduates who come to undertake further study at one of the three local universities, the Technische Universität Hamburg, the Musikhochschule in Hamburg and the Fakultät für Slawistik. Here they study for an MA or PhD in science and then use these higher educational qualifications to remain and make a life in Hamburg.

Two further categories of interviewees should be mentioned:

Those who have contracted cross-cultural marriages, marrying Germans. 
Second generation migrants, a group of crucial importance in the study of changing gender relations.

How does gender shape and reshape migration for the various categories of migrants?

These last two groups are particularly interesting. Spouses from cross-cultural marriages evinced a number of fascinating differences in their world view in comparison with couples where both were Macedonian. Such differences are particularly interesting not only as far as research into gender relations is concerned, but generally for the study of intercultural communication and especially of cultural misunderstandings. The other group, second-, or in some cases thirdgeneration migrants, reveal most clearly the changes in the traditional Macedonian collective habitus. More precisely, this refers to children who were born, brought up and educated in Hamburg. In their case, the process of upbringing or formation (Bildung), both within the family and in the wider social arena, is of particular interest. The formation process must take into account "social controls," the rules imposed by the social environment on one hand and the cultural origin of the parents on the other. This is especially noticeable with working-class interviewees and their children, where the gap between them in the way they conceptualize gender and inter-gender relations is striking. It is interesting to observe the way in which certain family habits are transformed, or are in the process of transformation, and new structures and dispositions of habitus are incorporated as a result of education. It is clear from my informants that conventional notions about the differences in upbringing according to the sex of the child are, consciously or unconsciously, being reinforced in the home in various ways. They directly reflect the age-old tradition of the division of labor according to sex. It is generally recognized that in earlier times, or among families originating from a rural environment, the division of labor according to these criteria was socially justified given the typical household economy - and even necessary for survival. Very many of my informants saw the traditional upbringing of male children as inculcating values and characteristics such as orientation towards the outer world, initiative, activity, decisiveness, independence and dominance, while the traditional upbringing of girls represents the opposite: orientation towards the inner world, passivity, obedience, dependence, need for protection and so on.(3) However, since second- or third-generation migrants undertake daily activities such as learning to play the piano, taking ballet lessons, 
learning foreign languages or participating in sport (football, tennis, judo, fitness), as well as attending elementary school, opportunities for traditional divisions to be broken down are considerable.

This phenomenon is connected with the process of "formation," understood in the broadest sense, as in the German Bildung. Formation in this sense refers not only to a given organization (such as the school), but also implies the broad processes through which "world- and selfreference points become qualitatively changed." In the context of modern life, therefore, formation must be understood as a "search" fuelled by a "play with uncertainties" [Marotzki 1990: 152, 154; cf. Bohnsack and Nohl, 2005: 374].

Initially, in discussing the relationship between migration, space and gender, it is necessary to pay close attention to periodization. More specifically, in the 1960's and 1970's more than 95\% of Macedonian migrants who were the main players in the emigration process were male. They then brought their wives over from Macedonia and built family life and households in Germany. By contrast, the last fifteen years have witnessed a great change in the traditional patriarchal paradigm of gender relations, since this was when the first organized group of nurses arrived. The resulting role reversal was experienced as a subversion of traditional Balkan masculinity, or even as a subversion of traditional power relations.

These young women now became the main players. Apart from the stimulus of a new career, they experienced the new space as an obligation upon themselves to take charge of family life and the domestic finances. They began by bringing their husbands over from Macedonia. The husbands were then forced into being at the receiving end of the wife's emancipation, though, as we shall see, this was not a permanent reversal. The situation was connected with the changed political situation in Germany in the 1990's, which unfortunately coincided with the impossibility of finding any employment in the first five years of residence. Instead they became house-husbands, responsible for the housework and children, while their wives went out to work. This period dealt a painful and crushing blow to their patriarchal vanity, though the pain may be expressed in various ways: with humor or anger, explicitly or implicitly. An analogous situation arises with another group, the "boys from Macedonia," that is to say, those young men who marry secondgeneration working-class female migrants. They too are forced into taking on the traditional female caring role. 
On the other hand, highly educated and qualified migrants (part of the brain drain) do not undergo any essential qualitative change in their gender relations after leaving their homeland. This is quite understandable, given that education, especially in the second half of the twentieth century, is the key factor in the creation of new cultural horizons, allowing traditional patriarchy to become history. Thus the time taken for such people to adapt to a new environment and accept a foreign culture is shorter, and comparison between the two countries here functions as two cultural grammars. In this context, I would like to discuss the significance of the brain-drain. Macedonian economists and sociologists mistakenly view the brain-drain as a matter of concern, but I would suggest that the process itself brings considerable social benefits. Attention should be drawn instead to the real problems that induce people to go abroad. The major argument in favor of the emigration of local expertise is well known: the expectation that sooner or later migrants will repay their homeland through knowledge transfer, by bringing in capital and facilitating business relations. My fieldwork data suggests, however, that there is another important advantage of the brain drain. When graduates contemplate the kind of reward they will get in Macedonia for their efforts in getting a degree, they inevitably consider going abroad. Despite their high grades and the receipt of a pen so generously awarded to the best students in the Electro-Engineering Faculty at the University of Sts Cyril and Methodius in Skopje, my informants could only get work selling computers and training keyboard operators in the early 1990 's, a time when computer technology was beginning to develop in Macedonia.(4) It was abundantly clear that the only thing that high grades did for these young professionals was open the door to graduate study in Hamburg. This situation therefore encourages them to invest even more energy on their educational qualifications. The result can be summarized as leaving one's homeland in the form of a broken habitus, where the basic concordance between habitus and field has been abolished. The habitus tends to create the field in the form of an important meaningful world based on values, in which the investment of energy is worthwhile. The field structures the habitus, and the habitus represents a product of that field. This means that discordance between the two may lead to the habitus being broken [Bourdieu 1996:161]. As a consequence, it can be argued that Macedonian society benefits from the emigration of the chronically unemployed. We can speak bluntly. The long-term unemployed are, de facto, a burden on society. That many smart and hardworking people in 
Macedonia are, through no fault of their own, part of that burden reveals the dysfunction of that society, but does not change the painful truth that they are a burden. Thus, the resignation these young educated people with potential feel towards a homeland that allowed them to leave it as a broken habitus is fully justified.

Nevertheless, each individual life trajectory, out of the multitude of life stories I recorded, represents nothing more than a variation in a collective habitus:

Since the history of the individual is not anything other than a certain specification of the collective history of its group or class, each individual system of dispositions may be seen as a structural variant of all the other group or class habituses, expressing the difference between trajectories and positions inside or outside the class. The "personal" style, the particular stamp marking all the products of the same habitus, whether practices or works, is never more than a deviation in relation to the style of a period or class so that it relates back to the common style not only by its conformity like Phidias, who, according to Hegel, had no "manner" - but also by the difference which makes the whole "manner" (Bourdieu 1999a:86).

How the space of life-styles reveals the two symbolisms of the "Walledup Wife" and "A Room of One's Own"

The matrix of inter-gender relations in a new environment corresponds remarkably to two contrasting metaphors ranging from the "walled-up wife," a Balkan metaphor for marriage, to a "room of one's own" at the other extreme. The image of the walled-up wife comes from that most famous of Balkan folk ballads, "The Ballad of the Walled-UpWife." The plot tells of a group of men who seek to construct a castle, monastery or bridge. Through supernatural means, whatever is constructed by day is undone at night. A dream revelation or some other extraordinary means of communication informs the would-be builders that the only way to break the negative magic spell is to sacrifice the first woman to come to the building site the next day. When the chief architect's own young wife arrives, she is duly immured [Dundes 1995:39]. "A room of one's own" refers to an essay by Virginia Woolf, to which I would like to give a symbolic dimension.(5) For Woolf a room of one's own offered a place where she could write. A natural symbol of detachment and calm, it stands as well for the material minimum of freedom, means and opportunity essential not only to a writer, but to women as a whole [Woolf 1959; Maumdar and McLaurin 1975: 255-56]. Woolf"s "sign" was thus conceived and felt as a rebellion against male-dominated society, and heralded a new cultural horizon. 
Not in all cases, but still in a significant percentage of working-class families and to a certain degree among high-school graduates, the traditional Macedonian patriarchal family is alive and well, judging by the traditional upbringing of boys and girls, the position of the wife in the same family, the inward orientation of women and girls, with passivity, obedience, subordinate position and reticence seen as virtues, and the boys brought up to be privileged, extrovert and so on.

At this point I would like to cite a case that clearly reveals the discrepancy between habitus (in the form of a tender-hearted traditional mother fearful for her daughter, who has become an underground train driver), and field (in this case, Germany as a country that imposes quite different existential and social parameters). The story, it should be noted, is not concerned with emotional reciprocity. On the contrary, the daughter, raised and educated in Germany, is not fearful or inhibited about public space and the experience that it offers.(6) It is only the mother who is upset.

Леле, тој прв работен ден на Клаудија како “Zugfahrer”...И баш тој ден многу врнеше, м`лскаше, и јас цела ноќ не сум спала. Цели перници мокри ми беа. Много сум се тресела. А Георги воопшто и не знаеше дека Клаудија тој ден почнуваше со работа и дека треба да вози. Е па не мора се мажот да знае!!! Како викаат мажите: “не треба се жената да знае, така и мажот има некои работи што не мора да ги знае.” Така ли е? (сите присутни се смеат).

(Oh, that first day when Claudia started working as a train driver. I didn't sleep all night. My pillows were wet with tears and worrying about how she was going to manage driving all day round Hamburg. And just imagine; the whole day the weather was bad; there was thunder and lightning, and I couldn't sleep. I was afraid and trembled for Claudia. And do you know, Gjoko (her husband) didn't even know that she was going to start her job that day. Well, men usually say "women don't need to know everything," so I guess there are things men don't need to know. Isn't that right?" (Everybody laughs)).(7)

Here I should mention another instance involving first-generation working-class migrants originally from a rural area in Macedonia. After many years the couple has a son, who is the fourth child in the family. After his birth the family starts celebrating his name day, Mitrovden (the Feast of St Dmitri, Nov 7th) as the main religious festival in the family. Every year they mark the day in great style (see front cover).(8) The paradigm of traditional patriarchal order can be observed functioning in this family in a number of ways, including what has been called the centrifugal and centripetal orientation in interviews, here in relation to the family photo collection. While the husband presented photos of their summer holidays in France, Spain and Portugal, or the construction of 
the first Macedonian church in Malmó in Sweden, and experiences from the Macedonian club and the Macedonian church in Hamburg - all typically male activities connected with the public sphere -, his wife chose photos connected with the typically female sphere, centered round the space of the home: family and religious customs, birthday parties and certain new German customs and rituals such as: $A B C$ Schütze (a bag of candies given to children on their first day at school), Nicolausfest (the feast of St Nicholas, Dec. $6^{\text {th }}$ ), German Christmas and especially Weihnachtmann (Father Christmas). All these are primarily focused on child rearing. This type of mental disposition was evident in almost all the working-class migrants interviewed.(9)

Another example in the same category further emphasizes the point:

"Сосем е нормално жената да чисти, да готви и да се грижи за децата, затоа што мажот е тој што треба да заработува за семејството и за дома!"

(It is quite normal for the wife to have to clean the house, cook and raise the children, because the husband has to earn enough money for the family and the household).(10)

From the ethnological point of view, what we have here is a manifestation of the opposition between a centrifugal, male orientation and a centripetal, female one, and as such, it is typical of traditional Balkan society, where this is seen as the correct way to organize domestic space. This phenomenon is doubtless also the basis of the relationship of each of the sexes to their "psyche," that is, as Bourdieu has argued, to their bodies and more precisely to their sexuality [Bourdieu 1999a: 92]. On the other side of the scale of values is Virginia Woolf's model, which in my data is reflected in a number of individual life stories in which Balkan masculinity is criticized.

We should now return to the first type of collective habitus, whose paradigm is the walled-up wife. The poet Goethe was appalled by what he considered the heathen barbarity of the ballad [Dundes 1995: 40], but later scholars have opened it up to a great variety of interpretations. One of the most interesting and insightful decodes the prison as a metaphor for married life, suggesting that the walling-up may express "the inevitability of a woman's fate: to be transformed into the foundations of a new construction, a new world, a new family that is not always very pleasant" [Parpulova 1984: 433]. By entering marriage, the woman is figuratively immured. She is kept behind walls to protect her virtue and to keep her confined. Furthermore, the fact that the man is willing to sacrifice his wife in order to build a bigger and better castle or bridge reflects the second-class status of women in such societies. In that male chauvinist world, the women's role is to stay protected from the outside 
world and to concentrate upon nurturing her infants (who should preferably be sons)! The ideal wife nurtures males, whether by bringing food to her husband as he works on a construction site or by breastfeeding her newborn son [Dundes 1995: 48].

Thus the feminist reading cogently argues that from India to the Balkans the plot is a death-laden metaphor for a marriage, in which the wife is forced to sacrifice her freedom of movement because of the demands of her husband and his family. What might this suggest in terms of the Balkan collective habitus, conceived metaphorically through the symbolism of being "walled up"? Here there is of course another possible perspective, that of the builder. It is obviously a matter of opinion whose story the ballad tells: the woman's tragic fate or the widower's tragic grief. We have discussed the feminine perspective. Seen from the builder's point of view, the metaphor can be called in Dundes' phrase, "a male edifice complex" [1995: 50]. In terms of my informants, men may try to express their masculinity by denying any dependence on women, but traditional ideology collapses when their wives (the young nurses we have already mentioned) take charge of family life and the household finances in the first five years of migration, while their husbands sit at home and learn German off the television. One should also bear in mind the ambiguity of the role of a "nurse." Both in her profession and her family her obligation is to care for others, especially her husband (the builder in a traditional male-dominated world). The work of the nurse, therefore, is paradoxically a reflection of the role of the ideal wife, whose highest virtue is to nurture the males in the family.

For this category of husband it is unpleasant to acquire the status of a "Duldung," a kept man, and from a gender perspective it is a painful blow to the male ego. However, after this initial period, all being well, integration into the new society in accordance with his personal capabilities and skills then follows. Very often our migrants in this category, however, get a job requiring lower qualifications than the one they had at home. This situation may well trigger the kind of painful guilt feelings that are traditional in women. As one nurse pointed out, despite her incredible good fortune and success in making a go of life in Germany, she suffered terrible pangs of conscience for having sacrificed her husband's career.(11) It appears that it is almost impossible to escape some aspects of the traditional gender relationship in this type of collective habitus, where the woman has been conditioned into possessing the qualities of reticence, obedience, over-developed conscience and even a sense of guilt. 
In this type of family the conventional male sense of shame appears as hubris (overweening anger and insolence), while female feelings emerge as reticence, which is seen as the sublime virtue; de facto, this pair of contrasting attitudes reveals deeply rooted structures and dispositions which have not changed, or have only slightly diminished in some Macedonian migrants despite long years of living in another society with a quite different culture. Family relations and family traditions of this kind which seem to reproduce a symbolic violence in gender relationships are demonstrably part of a cultural lag inherited from the country of origin that is characteristic of pre- or early modern times. By cultural lag I refer to mentalities, notions, attitudes, habits and ways of behavior observed during my research and which can be connected with Bourdieu's phenomenon of hysteresis of habitus. He argued that when people change positions, their habitus is sometimes no longer appropriate, calling this condition hysteresis. Hence it seems entirely to be expected that a revolutionary transformation of the deeply rooted structures of a habitus, which has been transmitted down the generations, is impossible. The relation between sex, gender and culture can be defined by seeing it in terms of the contrasting ideas of nature and culture, or by Bourdieu's precisely defined notion about the incorporation of the dispositions of a habitus, or simply the relation between the positions and the dispositions of a habitus. One must bear in mind Braudel's "la longue durée," the notion that any changes in mentalité and the individual worldview occur extremely slowly [Braudel, 1977: 47-85]. And according to Bourdieu, the body represents a social product which is the only tangible manifestation of the "person," and which is commonly perceived as the most natural expression of the individual's innermost nature [1999b: 192].

In discussing the division of labor according to gender, I am here focusing on the division of domestic labor, traditionally part of woman's sphere in the pre-industrial era. It is interesting to note that for almost all the German sons-in-law, by which is meant Macedonian men who marry Macedonian girls resident in Germany, or for the Macedonian husbands of the nurses, who have no right to work for five years after arrival in Germany, having to do the housework, a typically female activity, represents defeat and shame. However, this first period may be considered one of initiation, since as is clear from the later stages of their life stories, male patriarchal dignity does make a return. In the typical family where the women are the main providers, and the men have had the luck "thanks to a concurrence of events" to end up as their chosen 
ones,(12) the shame of having to do "female duties" in the household during this phase of their liminal status is often seen as to a certain degree legitimate. The feeling is not so overwhelming as to stop these husbands from taking on these duties, especially when they remember that the basic reason for migration was to escape from an unstable environment, particularly during the horrors of the Balkan crisis in the 1990 's. Thanks to the actions of their wives, they have acquired a more secure existence. Without exception, every interviewee agreed that the decision for the kind of break in their life history (Biographieeinschnitt) caused by migration was conditioned by the need to provide a more secure existence and a better future for their children.

On the other side of the scales is the Virginia Woolf model, according to which criticism of male-dominated societies is made public. Only a small number of female informants showed any real impetus in this direction, not only in the narrative of their life histories, but also in terms of their inner urbanization, a cognitive map expressing the space of the new lifestyle in a new society. Here I am thinking in particular of these migrant women's freedom of movement around the city and the creation of new social relations (friendships and activities) outside the home possible thanks only to migration. One of my female informants, a young nurse, conformed closely to the Woolf model (13). She was vocal in her protests about the subordinate position of women all around the world, and especially in Macedonian families. She was similarly outspoken in her criticism of the inequality in the upbringing of boys and girls, bitterly condemning the privileged position of males. Her criticism was marked by her highly positive evaluation of inter-gender relations in Germany. Her views had their roots in her own childhood and adolescent experiences at home with her parents in a small village near Ohrid, a very traditional upbringing which she felt had been highly disadvantageous for her. In her account of the more recent events in her life, she brought out the dynamism of her daily extracurricular activities; she would attend piano recitals or the dress rehearsal of Il Trovatore in the Hamburg Opera House, go regularly on outings, visit the Louvre and the Historical Museum in Hamburg, and attend fitness classes and other such cultural activities.

Another female informant, an educated woman, talked of the changes she had made to her life:

- Не можам да разберам, како таа може да живее во такви услови, едноставно да биде сопственост на мажот; да живее во дом во кој машката доминација е толку очигледна. Еве, на пример, во мојов случај, пред две години решив да се разведам. 
- Зошто?

-Па едноставно, нашиот живот стана многу здодевен и решивме да се разделиме. И така јас започнав еден сосем нов, поинаков живот во однос на тој претходниот. Да, навистина ми е сега многу интересно.

("I can't understand how she (one of the working-class informants, L.S.) can live in such conditions, still the property of a man, and in a house where male dominance is so evident. For instance, in my case, I decided before two years were up to get a divorce."

"Why?"

"Our life got very boring, and so we decided to get divorced. Now I've begun a life quite different from the one I had before. It really is very interesting.)(14)

We should not forget Bourdieu's comment when considering woman as passive victim or rebel against stereotyped gender relations:

All of these above mentioned situations are very understandable, considering the fact that, springing from the encounter in an integrative organism of relatively independent causal series, such as biological and social determinisms, the habitus makes coherence and necessity out of accident and contingency. For example, the equivalences it establishes between positions in the division of labor and positions in the division between the sexes coincide almost perfectly [Bourdieu 1999a: 87].

For most of my women informants such attitudes were alien. One such woman recounted her life history at a party on a religious holiday, presenting her marriage as the epitome of continuing harmony. Then shyly in a magnificent soprano voice she broke into the well-known Macedonian folk song “Зошто друга љубиш ти?” (Why do you love another). In so doing she revealed the true state of affairs, something she was not brave enough to admit openly.(15) This informant represents the victim heroine, who is confined within the walls of her home and who has given her loyalty to her husband by virtue of marriage to him. Of course, the sexual division of labor corresponds exactly to the traditional pattern. Part of this type of mental schema is her pride in her husband and son, and many other things that make up her own view of her married life as profoundly harmonious. This kind of example perfectly coincides with the group's deepest values, and its most fundamental beliefs.

If we bear in mind that western European countries are themselves open to criticism from feminist rebels against the patriarchal order noted by Virginia Woolf, the yawning gap between the two cultures (Macedonian as a typical Balkan culture, and German a West European) indicates the nature of the situation.(16) Nonetheless, for all my informants (regardless of sex) Germany represents the model of correct inter-gender relations. They all emphasized the respect and the equality 
that women have in this society. However, it was far from uncommon for this model to be presented as a statement, rather than as the result of personal experience.(17) As a rule, the experience of equality in the division of housework is rare, but there do exist households where equality is rapidly achieved, and operates smoothly:

-Божана /жена ми/ и јас секогаш заедно ги изврууваме домашните активности. Не треба да претстбавува никаков срам ако ма'от ги пере садовите, ја чисти куќата или пак готви. Кога сум јас на работа таа е одговорна за домаѓинството, а кога е таа надвор тогаш сум јас одговорен за готвењето.

(Božana (my wife) and I always do all the housework together. There is no shame in the husband washing the dishes, cleaning the house and cooking. When I am at work, she is responsible for the housework, and when she is out, I am responsible for the cooking.) (18)

On the other hand, changes in mentality are not always genuine. This relates in particular to working-class men, those who came as Gastarbeiter in the years between 1969 and 1973. In their early days in Germany in particular, they would declare that their aim was "to earn some money for two or three years so as then to go back to Macedonia." Almost all their wives were employed, and this situation engendered a temporary, false change in the mental structure of the typical Balkan patriarchal organization. While the women were at work, the men did all the housework, and vice versa, but this was seen as strictly temporary, changing when temporary migration became permanent.

I have come upon many cases where social inertia or the cultural lag mentioned above were very obvious. Here I am thinking of the typical hysteresis of habitus, where a social lag of this nature can flourish with ease; male domination and female passivity, self-indulgence and obedience all contribute to ensuring that this hysteresis of habitus fails to disappear among first- generation working-class migrants. More particularly, we cannot ignore the fact that a percentage of working-class women who, after regulating their status and deciding to stay in Germany, nonetheless choose to revert to their traditional commitments by giving up work and taking on the activities associated with home, family and child-rearing. Here we can bring in Durkheim's classic concept of the social division of labor (separating the work place from the home) as a crucial modifier for changing mental structures and creating a new morality [Durkheim 1998].(19) More specifically, though it may not be immediately apparent, Macedonian migrants (especially those from backward rural areas) manifest a deep-rooted male jealousy on one hand, and female shame and reticence on the other, resulting in strong feelings about female fidelity expressed in the insistence that 
women are confined to the home. This attitude, though not overt, can be discerned on several planes, such as in the unequal distribution of household duties as well as in the mental maps of migrants - that is to say movement around the city, and especially the notion of an inner urbanization, meaning adaptation to and familiarization with an urban lifestyle. In other words, the process of urbanization should involve a change of mentality, because an urban lifestyle offers and requires qualitative new spatial, temporal and, above all, social organization. However, despite the plethora of opportunities offered by a large industrial city like Hamburg, many of the women experience an inner reduction in their possibilities for experience. They hardly ever go out alone for a walk or for a drink in a café. Their situation represents hysteresis that is fully justified and understandable in the context of their collective habitus. The most typical forms of entertainment and "movement in the city" in their case are visits to family, lively weekend barbecues in their country cottages outside Hamburg, as well as the celebration of Orthodox customs under the auspices of the Macedonian church of St.Georgi Kratovski. These activities may all be defined as part of a working-class leisure strategy, the situation representing an almost perfect coincidence between physical and social space.

So, "through the habitus, the structure which has produced it governs practice, not by the processes of a mechanical determinism, but through the mediation of the orientations and the limits it assigns to the operations of invention of the habitus. As an acquired system of generative schemes objectively adjusted to the particular conditions in which it is constituted, the habitus engenders all the thoughts, all the perceptions, and all the actions consistent with those conditions, and no others. This paradoxical product is very difficult to conceive, only so long as one remains locked in the dilemma of determinism and freedom, conditioning and creativity. Because the habitus is an endless capacity to engender products - thoughts, perceptions, expressions, actions - whose limits are set by the historically and socially situated conditions of its production, the conditioned and conditional freedom it secures is as remote from a creation of unpredictable novelty as it is from a simple mechanical reproduction of the initial conditionings" [Bourdieu 1999a: 95].

The deep roots of patriarchy are revealed in a number of instances in my informants' life histories, often of a somewhat depressing nature. Adjusting to modernity in the form of the new conditions prevailing in a big city can be a very pleasant process, but unfortunately it hovers on the 
boundary of the impossible and the prohibited in the functioning of the collective habitus. Thus, while these women become accustomed to the city style of life and the new opportunities that present themselves, they themselves experience a terrible ambivalence. A number of autobiographical sequences were described by these female interviewees with ambivalent feelings of happiness, shame and pangs of conscience, though one should expect nothing else, given that we know how durable and transportable the dispositions of habitus are. One instance related to a workplace Christmas party, for which invitations were issued by the boss of the company where one of my informants worked. Her comments reflected her ambivalence:

Леле каква чест беше тоа; тоа беше најубавиот момент во мојот живот.

Знаеш ли каква почит е тоа кога директорот ќе те покани на дочек. ....

Ама, не, сепак, не е фер жената сама да искача во град додека мажот седи дома и гледа телевизија.

(Wow, what an honor that was; that was the most wonderful moment in my

life. You know what an honor it is when the boss invites you to a party...But still, it isn't right for a woman to go out alone while her husband stays at home watching TV).(20)

Other accounts are along the same lines:

Толку е убаво овде у Германија, секој маж и помага на жената; секоја сабота јас гледам карши во зградата како мажите ги перат прозорците!!! -Дали твојот маж ти помага дома?

- (пауза),... хм, (пауза), да, помага...., знаеш, зет ми многу и помага на ќерка ми, тие сѐ работат заедно.

("It is so nice here in Germany, all the husbands help their wives; every Saturday I can see husbands washing the windows!!!"

"Does your husband help you in the house?

“..(a pause), Oh, (pause)...well yes, he does, ... but you know, my son-in-law helps my daughter a lot; they do everything together!") (21)

Another significant example that relates to traditional patriarchal culture concerns a pleasant couple, a cohabiting divorced man and a widow, a fact not mentioned in the recorded version of their life histories. Not surprisingly, the idea of cohabitation is not just inconceivable but also banned in traditional Macedonian morality. In German society such relationships are accepted. In this case, the ambivalence was also the essential feeling marking the tearing of the habitus and this has emerged from the discrepancy between the habitus and the field (Germany), which qualitatively imposes somewhat different existential and civilized values compared to traditional Macedonian peasant culture.(22)

At this point I would like to cite a couple of nice examples where the ambivalence resulting from the hysteresis of the habitus was a source of humor: 
- Овде во Германија заедно и мажот и жената ги делат обврските. Тука не постои само женска работа; мажот треба да и помага на својата жена. (...) Јас се чувствувам како Германец. Мојата сопруга (Германка) е веќе две години на породилно боледување. Еве, за два месеца таа треба да се породи со второто бебе, и автоматски таа ќе остане дома уште три години (под социјално) и без работа. За целото тоа време јас морам да заработувам пари како заботехничар.

(Here in Germany both husband and wife should divide the duties. There is no such thing as purely female work; the husband should help his wife.... I feel like a German. My wife (a German) has been on maternity leave with our son for two years. In two months the second baby is due, so automatically she will be at home for another three years (on public welfare) and without work. In that time as a dental technician I'm going to have to earn a lot of money.)(23)

Further on in his life history, he jokingly mentioned that he loved children and that it would be no surprise if his wife got pregnant again (everybody laughed). To my question as to whether he helped his wife with the household chores and the baby, he answered:

“Тоа е точно; секој маж мора да и помага на својата жена и да се грижи за бебето, но сепак, ти знаеш дека сум јас многу зафатен. Јас морам да работанм по цели денови во мојата ординација за да заработам пари за семјствот." (сите се смеат).

(That's true; every man should help his wife and look after the baby, but, you know, I am too busy. I have to work in an office all day, earning money for my family. (Everybody laughs)) (24)

The following story about the combination of Macedonian and German customs at the wedding of a Macedonian man and a German woman in 1994 in Štip as a dental technician (a small town in eastern Macedonia), offers another interesting perspective on gender attitudes. As was customary in Macedonia, the bride was taken from her home, and there then followed the marriage ceremony at an Orthodox church in Stip, and the giving of the dowry. The customs were performed with great gusto and an element of humor and parody. There was one point at which it looked like a good moment to insert a German wedding custom into the proceedings:

Тони: Ние сакавме да вклучиме еден германски обичај кога бевме во ресторанот. Имено, невестатљ става една плава манжетна високо на ногата, на бутината. Таа ја подига таа нога и ја става на столче. Потоа , таа ја подига венчаницата високо до бутината. За тоа време сите играат, а неколку ергени, млади неженети момчиња ( ) се такмичат на тој начин, што кој ќе даде повеќе пари, тој ќе биде победникот.

$\underline{\mathrm{S}}$ : И кој беше победникот во вашиот случај?

Тони: Никој. Јас не дозволив. Јас не дадов да се изведе овој обичај на нашата свадба. (сите се смеат).

S: $\quad$ Ти не дозволи? Ах Тони, Тони!!! (сите се смеат). 
Биргит: (со допадлива интонација): Беше многу жешко, знаеш. Тоа беше 3ти септември и во Штип беше околу 41 степен, така што не можев да носам најлон чорапи за време на свадбата (сите се смеат).

(Tony We thought about including a German custom when we were in the restaurant. In particular, the one where the bride wears a blue garter round the top of her thigh. She lifts her leg and places it on a chair. Then, she lifts her dress up as far as the garter. While everybody else is dancing, a few young single men compete to be the person who gives the most money, and so wins the right to remove the garter.

S. So, who was the winner in your case?

Tony Nobody. I wasn't having it. This didn't happen at our wedding. (Everybody laughs).

S. $\quad$ You wouldn't allow it? Oh, Tony, Tony!!! (Everybody laughs).

Birgit (jokingly) It was very hot, you know. It was the third of September, and the temperature in Štip was about $41^{\circ} \mathrm{C}$, and I couldn't face wearing stockings at the wedding. (Everybody laughs).) (25)

$$
* * * * * *
$$

As we can see, all these life experiences and descriptions that are a product of traditional ideologies function as hysteresis of habitus (26) whereas the effort to preserve such a structure is already on a downward path historically. The structure cannot be functionally justified, but is actually only abolished in the second or the third generation. The weakening of patriarchy in the area of male and female participation in the organization of the family and economic life can be felt in many personal testimonies from informants, particularly those from the younger generation of migrants, where the following notion is expressed, albeit with slight variations:

Тони: Биргит и јас сѐ сами постигнавме во во животот. Ние сами, јас и

Биргит. Знаеш, тоа е малку проблематично, затоа што доколку сакаш нешто да постигнеш во животот мораш за се́ сам да се избориш, затоа ние двојцата мораме да работиме, посебно во последно време. Знаеш, порано имаше случаи кога можеше мажот да работи, а сопругата да седи дома и да ги чува децата. Ама ситуацијата во нашето семејство е малку поинаква. И не е само во нашето семејство, еве исто е и кај Лиле. Таков е случајот во многу семејства - двојцата сопружници мораат да работат.

(Birgit and I have achieved everything in life on our own. The two of us, by ourselves, just me and Birgit. Well, it's a bit problematic, in the sense that if you want to have things in life, if you, say, want to indulge yourself in some way, then both of you have to work, especially nowadays. Not that the past was any better; there were some situations where one of the spouses had to work and the other to stay home with the children. But the situation in our family is a bit different and difficult too. Not just in our family, but in Lile's too. It's what happens in most families - both spouses have to work.) (27)

Here I should note that the Macedonian club and church enable working-class migrants (and to a certain extent people from other 
categories) not only to socialize but also to see themselves as part of a big happy family. This sense of unity can be seen not only in their shared traditional attitudes to inter-gender relations, but also more generally in their experience of migration as a Biographieeinschnitt (a biographical break), because the life history means subjective self interpretation and evaluation of one's whole life, not the statistical evidences in the life course. On the other hand, we have the individualists (the highly educated) whose dynamic trajectories in life make it logical for them to accept the gender relations associated with this sort of path, assisted by daily encounters that determine their life-style, leading to gender relations veering towards equality between the sexes such as are conventional in highly industrialized societies. All these practices and habituses may be summarized in Bourdieu's statement about the orchestration of the habitus:

"One of the fundamental effects of the orchestration of the habitus is the production of a commonsense world endowed with the objectivity secured by a consensus of the meaning (sense) of practices and the world, in other words, the harmonization of the agents' experiences and the continuous reinforcement that each of them receives from the expression, individual or collective improvised or programmed (commonplaces, sayings), of similar or identical experiences" [1999a: 80].

\section{Conclusion}

In the light of the empirical analysis of the two culture-specific conventions embodied in the two symbols I have employed, I can conclude this short piece of research by saying that the passage from a subordinate to an equal position clearly depends on educational level. I would like to re-emphasize the relation between the dispositions and positions of the habitus, following Bourdieu's view that "the habitus is modifying and transformational within the borders of its own structure" in the sense that man's spirit is socially limited, socially structured, and this is the product of his education and formation [1996:160].

The data from my fieldwork very clearly links the symbolism of the "walled-up wife" and "The Room of One's Own" to the ongoing traumatic relations prevailing in the battle of the sexes, which would help to explain why they continue to be a painful and poignant reminder of the difficulties of balancing a career and marriage for men, and achieving freedom of movement and opportunity for women. The future of traditional gender relations is certainly in doubt among second- or thirdgeneration Macedonian migrants in Hamburg. As I had reason to observe in my fieldwork, the very word "liberation" in the phrase "women's liberation" is linked to the basic complex of ideas that generated the 
"walled-up wife" metaphor in the first place, a complex that insisted that women were not free, not liberated. In time, the liberation of women may make traditional gender relationships obsolete and inconceivable. I am thinking in particular about the children educated in Germany and also the younger generation of Macedonian intellectuals (the so-called brain drain). Relatively little time has passed since change got under way, but Dundes' hypothesis may be becoming reality: "As more and more women become builders of bridges, castles, and dams, perhaps, it will be the men who will be forced to become the 'victims' of their wives' ambitions" [1995: 51].

\section{NOTES}

1 Bourdieu's defines habitus as: "The structures constitutive of a particular type of environment (e.g. the material conditions of existence characteristic of a class condition) produce habitus, a system of durable, transposable dispositions, that is, as principles of the generation and structuring of practice and representations which can be objectively "regulated" and "regular" without in any way being the product of obedience to rules, objectively adapted to their goals without presupposing a conscious aiming at ends or an express mastery of the operations necessary to attain them, and being all this, collectively orchestrated without being the product of the orchestrating action of a conductor (Bourdieu, 1999a:72).

2 Held in the Archive of the Institute of Folklore "Marko Cepenkov," in Skopje (tapes nos 3994-4021). My thanks are due to the Institut für Volkskunde in Hamburg, and especially to Prof. Albrecht Lehmann, who acted as mentor during my postdoctoral research.

3 B. G. (f), 58, arrived 1972; D.G. (m), 58, arrived 1969; T. G. (m.), 28, arrived 1990; A. N. (m.), 57, arrived 1970; R. N. (f.), 55, arrived 1972; A. N. (m), 40, arrived 1992; L. N. (f.), 39, arrived 1991; R. I. (f.), 58, arrived 1972; G. I. (m.), 58, arrived 1970; J. S. (f.), 23, arrived 1991; V. Š. (m.), 39, arrived 1993; G. K. (m), 58, arrived 1971; V. B., (f.), 62, arrived 1971; P. S. (m.), 58, arrived 1971; A. S. (f.), 56, born in Hamburg; Z. G. I. (f.), 36, arrived 1991; M. I. (f.), 51, arrived 1980; S. S. (f.), 33, arrived 1995.

4 S. Š. (f.) and N. Š. (m.) both b. Skopje, 1973, arrived 1995.

5 "A Room of One's Own" is based on two papers read to the Arts Society of Newnham College, Cambridge and the One-Damned-Thing-After Another Society at Girton College, Cambridge in 1928.

6 K. G. (f), (b. Hamburg, 1978). This woman, who is typical of my secondgeneration migrant informants is the chief player in her new family. She is in charge of household finances and family life as a whole, while her Macedonian husband is responsible for the house (T. G., b. Strumica 1978, arrived 1990).

$7 \quad$ R. I. (f.), b. 1948 in Veljusa, Strumica area, arrived 1972.

8 R. N. (f.), b. Kavadarci, 1951, arrived 1972.

9 Almost all of the twenty interviews conducted with this category of migrants reveal a traditional patriarchal orientation in the self-transformational process of the individual's biography. For example, almost all the husbands laid emphasis on the outside world as it related to family life (the world of the workplace; politics; the 
Macedonian Club and church). All the female life histories focused on house, family and in particular the rituals connected with child rearing [AIF, tapes no 3994; 3997; 4001, 4006, 4010, 4011, 4018, 4020, 4021]. Those activities, characteristic of the pre-modern era, might be defined as the collective unconsciousness, these migrants' lack of awareness of another epoch. However, I found one instance of a cross-cultural marriage among working-class migrants, where the stereotypical patriarchal order had been abolished. The typically German wife was very forceful character, and her life history reflected a lifestyle in a highly industrialized society, where the qualities of mobility, disassociation, subjectivity and accentuated individualism are emphasized (P. S. (m.), b. Volče a village near Makedonski Brod, 1948, arrived 1971, and A. S. (f.), b. Hamburg 1950 [AIF, tapes no 3999-4000]. Such an outlook is still alien to the typical Macedonian wife and mother.

10 R. N. (f.), b. Kavadarci, 1951, arrived 1972.

11 An amusing situation arose when I asked them why they did not go back to Macedonia, where the husband would be able to follow his own profession. Their answer was: "Па не сме будали. Едвај успеавме да се спасиме од една несигурна земја ...(Пауза), така да...." (Well, we're not fools. We only just managed to get out of that unstable country, (pause) ... so now...) (L. N., (f), b. Prilep 1966, arrived 1991, and A. N. (m), b. Strumica, 1965, arrived 1992 [AIF, tape no.3996]).

12 We should not ignore the fact that, in a number of cases, the system of arranged marriages is evidently still operating. Examples from my data come from Štip (T. G. (m.), b. 1963, and B. G. S. (f.), b. 1963 [AIF, tape no. 3998]; Strumica (C. G (f.), b. 1978, and T. G. (m.), b. 1978 [AIF, tape no. 4012]; J. Š. (f.), b. 1973 and V. Š. (m.), b. 1966 [AIF, tape no. 4008-09].

13 Ž. G. I. (f.), b. Konjsko, in the Ohrid area, 1969, arrived 1991 [AIF, tape no.4002-03].

14 M. I., b. Skopje 1955, arrived Hamburg, 1980.

15 R. I. (f.), b. Veljusa, Strumica area, 1948, arrived 1972.

16 As Bourdieu has demonstrated, some forms of cooking symbolize a certain state of female existence and the sexual division of labor (a woman entirely devoted to housework is known in France as a "pot-au-feu"), just as putting on one's slippers before dinner symbolizes the complementary male role. So, the particularly high consumption of carpet slippers by French working-class women (both urban and rural) no doubt reflects their relation to the body and to self-presentation entailed by confinement to the home and to domestic life (Bourdieu, 1999b:187). In other words, as Woolf insightfully noticed long ago, the feminine is universal and yet transitory, and can be expressed only by brittle half-phrases, symbols, poetry [Woolf 1959]. Another of Bourdieu's statements is relevant here: As in every society dominated by male values - and European societies, which assign men to politics, history or war and women to the hearth, the novel and psychology, are no exception - the specifically male relationship to sexuality is that of sublimation, the symbolism of honor tending to reject immediately any direct expression of sexuality in favor of encouraging its transfigured manifestation on the form of manly prowess [1999a: 92]. In this context I would like to mention another example of this kind of cultural lag, a theme which is very much to the fore in the gender-oriented Nordic folkloristics headed by Satu Apo, Ali Nenola and Sinnika Vakimo. The existence of patriarchy or male dominance, which is not admitted by many today in Finland or indeed other Nordic countries, has been strongly criticized. As they point out, complaints about the obviously illusory equal paradise for women are met with remarks such as: "but think how good your situation is compared to other parts of the world" and "you are complaining about trivialities." And, of course, that is how it looks if we compare our 
situation to that in countries or societies where women are still the property of men, or if we compare the present situation to Finnish or Nordic society in pre- or early modern times when patriarchy and male dominance in the family and society were recognized as natural or divinely ordered [Nenola, 2004: 3-6].

17 I found some cases, even in cross-cultural marriages, where this ideal model did not operate. For example, take V. B. (f.), who was born in a village, whose name ironically is German, in the Kriva Palanka area in 1944. She came to Hamburg in 1971, where she married a German, but remains the person who does most of the household chores. There is also T. G. (m.), born in Štip, arrived Germany 1991, who now has a German wife. In the early years, he did all the housework, but after he was allowed to remain in his new country, traditional male dignity reared its head, and he handed over the running of the household to his young German spouse, the mother of their children. I recorded approximately twenty interviews with Macedonian couples where the women were responsible for the almost all the household chores.

18 D. G. (m), b. Skopje, 1948, arrived 1969.

19 A significant number of informants I met had found the change from the former domestic arrangements to the new urban style of life (which they saw as paid labor in a highly industrialized society) a very painful one.

20 R. I. (f), b. Veljusa, Strumica area, 1948, arrived 1972.

21 R. I. (f), b. Veljusa, Strumica area, 1948, arrived 1972.

22 G. K. (m.), 58, arrived 1970, and V. N, (f.), 55, arrived 1971 [AIF, tape no. 4006]

23 I. S. (m.), b. Hamburg 1978 [AIF, tape no 4017]

24 I. S. (m.), b. Hamburg 1978 [AIF, tape no 4017]

25 T. G. (m), b. 1963 in Štip, arrived 1991, and B.G.S. (f), b. 1963 in Hamburg.

26 Here I am thinking of first-generation working-class migrants, or instances where their children were raised and educated in small rural areas and provincial towns in Macedonia, only returning to Germany during puberty.

27 T. G. (m.), born 1963 in Štip, arrived 1991 [AIF, tape no 3998].

\section{LIST OF INFORMANTS QUOTED IN THE ARTICLE}

T. G. (m), born 1963 in Štip, arrived in Hamburg in 1991.

B. G. S. (f), born 1963 in Hamburg.

B. G. (f), born 1948 in the village of Drdanje, Rosoman area, arrived in Hamburg in 1972.

D. G. (m), born 1948 in Skopje, arrived in Hamburg in 1969.

T. G. (m.), born 1978 in Strumica, arrived in Hamburg in 1990.

K. G. (f), born 1978 in Hamburg.

A. N. (m.), born 1949 in the village of Drenovo, Kavadarci, arrived in Hamburg in 1970.

R. N. (f.), born 1951 in Kavadarci, arrived in Hamburg in 1972.

A. N. (m), born 1965 in Strumica, arrived in Hamburg in 1992.

L. N. (f.), born 1966 in Prilep, arrived in Hamburg in 1991.

R. I. (f.), born 1948 in Veljusa in the Strumica area, arrived in Hamburg in 1972.

G. I. (m.), born 1948 in Strumica, arrived in Hamburg in 1970.

J. S. (f.), born 1973 in Strumica, arrived in Hamburg in 1991.

V. Š. (m.), born 1966 in Strumica, arrived in Hamburg in 1993. 
Gj. K. (m), born 1948 in Kavadarci, arrived in Hamburg in 1971.

V. B. (f.), born 1944 in the village of German in the Kriva Palanka area, arrived in Hamburg in 1971.

P. S. (m.), born 1948 in Volče, a village near Makedonski Brod, arrived in Hamburg in 1971.

A. S. (f.), born 1950 in Hamburg.

Ž. G.I. (f.), born 1969 in Konjsko, in the Ohrid area, arrived in Hamburg in 1991.

M. I. (f.), born 1955 in Skopje, arrived in Hamburg in 1980.

S. S. (f.), born 1973 in Skopje, arrived in Hamburg in 1995,

N. S. (m.), born 1973 in Skopje, arrived in Hamburg in 1995.

I. S. (m.), born 1978 in Hamburg.

\section{WORKS CITED}

Braudel, Fernand 1977. Geschichte und Sozialwissenschaften. Die „longe durée“. In: Honegger Claudia (Hg.): Schrift und Materie der Geschichte. Vorschläge zur systematischen Aneignung historischer Prozesse. Frankfurt am Main: S. Fischer, 47-85.

Bohnsack, Ralf and Arnd-Michael Nohl 2005. "Youth Culture as practical innovation. Turkish German youth, 'time-out' and the actionisms of break-dance." European Journal of Cultural Studies, 6 (3): 367-86.

Bourdieu, Pierre 1999a [1972]. Outline of a Theory of Practice. Cambridge: Cambridge University Press.

London: Routledge.

1999b [1979]. Distinction. A Social Critique of the Judgment of Taste.

Bourdieu, Pierre and Loïc J. D. Wacquant 1996 [1992]. Reflexive Anthropologie.

Frankfurt am Main: Suhrkamp.

Dundes, Alan 1995. "How Indic Parallels to the Ballad of the "Walled-Up Wife"

Reveal the Pitfalls of Parochial Nationalistic Folkloristics." Journal of American Folklore 108 (427): 38-53.

Durkheim, Emile 1998 [1930]. De la division du travail social. Paris: Quadrige/PUF.

Majumdar, Robin and Allen McLaurin (eds) 1975. Virginia Woolf: The Critical Heritage. London and Boston: Routledge \& Kegan Paul.

Marotzki, Winfried 1990. Entwurf einer strukturalen Bildungstheorie. Biographietheoretische Auslegung von Bildungsprozessen in hochkomplexen Gesellschaften. Weinheim: Deutscher Studienverlag.

Nenola, Ali 2004. "On power and violence in patriarchal households." FF Network, 27: 3-6.

Parpulova, Lyubomira 1984. "The Ballad of the Walled-Up Wife: Notes about Its Structure and Semantics." Balkan Studies, 25: 425-39.

Woolf, Virginia 1959. A Room of One's Own. London: Hogarth Press. 